\title{
Economic Action, Fields and Uncertainty
}

\section{Doris Hanappi}

\begin{abstract}
Pierre Bourdieu's field and habitus approach to the economy offers rich theoretical presuppositions of the interrelationship between social structure and agency, but they have not yet been sufficiently integrated into economic sociology. This article outlines the key theoretical assumptions of this approach in relation to those of the embeddedness tradition. Bringing the elements of field and habitus to the center of attention helps in examining how cognitive and historical factors matter for explaining individual action. It integrates different notions of uncertainty in economic literature into the discussion of the underlying action principles of the Bourdieuian approach. The study concludes that only a historical perspective which integrates social, structural and cognitive analysis can adequately explain the generation, reproduction, and transformation of individual action itself. The article sketches the broad conception of such a theoretical synthesis in the conclusion.
\end{abstract}

Keywords: economic man, economic sociology, embeddedness, self-interest, uncertainty

JEL Classification Codes: D03, D81, D85, Z13

The critical assessment of rationality in economic action is a dominant theme of many scholars in socioeconomics and economic sociology who identified uncertainty as the foundation for a critique of rational actor models and for the introduction of alternative approaches. Informed by the insight that actual decision making could not fit the rational paradigm originating from a world of complete information, independent decision making and fixed preferences, many economists have developed new approaches to reconstruct rational action. Included among them are the

Doris Hanappi is a researcher at the Swiss National Center of Competence in Research LIVES (NCCR LIVES) within which she holds advanced research positions at the University of Geneva and University of Lausanne. Initial parts of the paper were written during the author's engagement at the Laboratoire d'étude des Parcours de Vie, at University of Lausanne. Funding for this research was provided by NCCR LIVES. The author thanks Laura Bernardi, Michel Oris and two anonymous referees for their helpful comments. E-mail address: doris.hanappi@unil.ch. 
prominent attempts by Frank Knight, through his work on Risk, Uncertainty, and Profit (1921), and by Herbert Simon (1957) through his notion of bounded rationality (for similar views see Arestis 1992 and Garner 1982). The discussion of bounded rationality has become important even in the game theoretical approaches to uncertainty and information (see for instance George Akerlof 1970 and Michael Spence 1974), often with the aim of refining the rational actor models.

Another strand of research originates from evolutionary economics as proposed by Richard Nelson and Sidney Winter (1982, 2002). They developed a concrete analysis of cognitive and structural foundations of technological innovations. In sociology, Harrison White (2002) provided a network-based approach to markets in which embedded agents learn from each other through social interaction. Network sociologist Marc Granovetter is prominent in this regard. He was innovative in introducing the relational basis of economic action by rejecting the homo economicus in its pure, determinist version that, as he formulates, "disallows any impact of social structure and social relations" (Granovetter 1985, 483). ${ }^{1}$ In contrast, Karl Polanyi ([1944] 2001) argues for the generic notion of homo economicus as historically specific and institutionally embedded.

This paper forms part of a broader discussion on the cognitive and structural foundations of economic action under uncertainty within the current forms and structures of the modern economy. Its purpose is to assess the value of Bourdieu's (2005a, 2005b) field and habitus concepts in the analysis of cultural and symbolic forms of economic action, particularly if such a theory emphasizes the social mechanics of the market field. The field notion refers to the social space as a system of positions and relations in which the habitus operates. The habitus is understood as the set of relatively durable dispositions and schemata of thought and perception. It is considered a valuable alternative to the rational logic of the ahistorical and often isolated actor as assumed in economic orthodoxy. It allows to link social structure to the individual and its past experience. Given this journal's readership, the paper is intended to spread awareness among economic sociologists, network theorists, and socio-economists about the theoretical and empirical richness of Bourdieu's approach to the economy. ${ }^{2}$

This paper is organized in the following steps. The first section introduces Bourdieu's understanding of the economy and his critical response to the embeddedness tradition. Economic reason and its underlying central categories habitus, field, and capital are discussed by pointing at three key aspects: the dimension of time, the role of power struggle and the generative nature of the habitus. It is then followed by the argument for the reasonability of strategies oriented toward rule following, on the one hand, and innovating on the other. Such a perspective is expected to give more prominence to the process of reproduction of strategies and social structure over time, if one would not account for the specific conditions that facilitate a generative, and thus innovative, rationale, rather than a reproductive one.

The paper integrates, therefore, different types of uncertainty - particularly, procedural (e.g., Dosi and Egidi 1988) and fundamental uncertainty (Dequech 2001), into the discussion about economic action to link Bourdieu's economic reason to 
uncertainty and change. Here, the paper partly incorporates, but qualifies, the criticisms of Bourdieu's theory for not paying enough attention to the possibility of creativity and structural change. The subsequent section focuses on one specific form of action, market signaling. It illustrates in what way Bourdieu's approach to the economy may lead to different conclusions with respect to one of the most prominent attempts in network analysis, the network-based market model developed by Harrison White $(1981,2002)$. His work marks a turning point from the classical structuralism toward an integration of structural and cultural elements into the analysis of social networks (Emirbayer and Goodwin 1994; Fuhse and Mützel 2010).

In the concluding section, the paper argues against mutual exclusion of Bourdieu's approach and the embeddedness perspective. It points out that economic action may be best understood as resulting from socially situated cognition and sociocultural construction of markets over time. Such a theory provides for an analysis of the cognitive and structural dimensions of market transformations, while an account of different conditions of uncertainty allows for a better identification of when change may occur, and thus innovation also.

At the same time, as markets have to deal with uncertainty, mere resource flows are inadequate in guiding action. Therefore, they have to be supplemented with factors, such as habits or creativity, which may differ among agents, and under procedural and fundamental uncertainty. The analytical constructs of field and habitus, as Powell and DiMaggio (1991) note, have marked the cognitive turn in social theory, a shift in the emphasis from the social psychology of values, norms and attitudes, to classifications, routines, scripts, and schemata (see also Widick 2004, 203). They provide network analysis with a stronger conceptualization of the agent to analyze the cognitive and motivational logics of action in a macro-social context.

\section{Bourdieu's Criticism of Embeddedness}

With his notion of the economy as a field, Bourdieu provides an alternative approach to the embeddedness concept, which he criticizes in at least three ways: First, he substitutes the a-historical nature which characterizes the embedded social actors in Granovetter's and Polanyi's theory by the principle of historicity highlighting transformation processes. Second, he complicates the idea of network flows, which are explanatory for embedded action, by the element of power struggle as the mechanism co-constructing field and habitus. Third, he replaces the principles of economic rationality which motivate most embedded social actors by the principle of reasonability resulting from the encounter of actors with individual dispositions and cognitive schemata in the economic field. ${ }^{3}$ Even though it is not the goal of this paper to present Bourdieu's theory of action in a comprehensive perspective, the following sections show how Bourdieu's work offers ways of dealing with the above mentioned aspects, and point at the relevance of his historical approach to understanding the evolution of fields and factors that can transform them. 


\section{Social Space and the Dimension of Time}

Most neoclassical economists would assume the process of market coordination and study the qualities of the market without understanding how the market actually came about (see Boyer 2008). Most economic sociologists, instead, would provide an analysis of how markets and institutions emerge, and at the same time discharge the neoclassical framework whose product is the market of pure and perfect competition (Garcia 1986). ${ }^{4}$ For Bourdieu and the work he inspired in economic sociology, every market is a result of interactions between actors. These actors govern the framing of game-rules to ensure the smooth adjustment of supply and demand. On a general level, this does not seem to differ much from Granovetter's and Polanyi's embeddedness approaches, if Bourdieu were not to pay more attention to the dimension of historical time, as opposed to time, as regarded by economists which is that of calculation, anticipation and movement toward economic equilibrium (Boyer 2008).

Allowing for the dimension of time serves as a starting point for Bourdieu's market analysis. A market, that is to say a field, is characterized by a patterned set of practices that suggest competent action in conformity with rules and roles (Bourdieu 1977). It is made up of a structure of actual and potential relations (Bourdieu and Wacquant 1992). Bourdieu's own vision of the market field is well expressed in the following statement from Principles of an Economic Anthropology:

What is called the market is the totality of exchange relations between competing agents, direct interactions that depend, as Simmel has it, on "indirect conflict," or in other words, on the socially constructed structure [of the field] of the relations of force to which the different agents engaged in the field contribute to varying degrees, through the modifications they manage to impose upon it, by drawing particularly, on the state power they are able to control and guide. (Bourdieu 2005a, 81)

The transformation of the rules of the game shapes the functioning of the field. This has further implications for historical transformations of the market field itself. First, market fields are not closed entities. Second, the relationship between fields and agents is circular, in that the involvement in a field shapes the agent's perceptions and dispositions. These in turn, shape actions that reproduce the field (cf. Crossley 2001). ${ }^{5}$

An example of the market analyzed as a social construct can be found in Bourdieu's housing survey (Bourdieu 2005b). It showed that people's propensity to buy, rather than to rent, depended on what social group they belong to, what their cultural habits were, and the fact that supply and demand were socially coconstructed. One may describe these interactions on the housing market in the form of a three-way relation between the buyer, the seller, and the social space with all its legal environment and common practices. This market, as specific social space, has its own logic, which not only shapes the particular characteristics of that space, it also moderates, as Rainer Diaz-Bone $(2006,43)$ notes, the way in which external factors 
impact the market itself (see Florian and Hillebrandt 2006). At the same time, homologies between positions in a specific social space and in a particular market are interpreted as resulting from individual action.

To summarize, Bourdieu emphasizes the social-historical dimension for the construction of the market. Accordingly, the market is an interplay between individual agency, field structure, and external factors (such as state power) over time. This direction of research on markets has been systematically pursued in the United States by economic sociologists, for instance Neil Fligstein (2001) who developed his political-cultural approach, and White (2002) who conceived the idea of networkbased self-reproducing markets. Both attempts were strongly informed by Bourdieu's field construct.

\section{Power Struggle Constitutes Fields}

The second aspect of embeddedness criticism relates to the idea that fields and habitus are co-constructed during a power struggle.

In most economic theories, the market is the main authority for coordinating the behaviors of decentralized agents. These agents are assumed to have the same amount of influence over each other, or no influence at all in the case of perfect competition. Bourdieu's economic sociology however insists on the idea that whatever be the field, certain agents have more power than others do. They face inequality of opportunity as their resources are unequally distributed (Bourdieu 2005a, 77).

Resources, namely the various forms of capital, constitute the market field as they generate counter-positions due to competition and conflict over the reproduction of unequal distribution of capital. The stock of capital is a fundamental resource to gain advantage within a field. The latter is so constructed that agents who occupy similar or neighboring positions are placed in similar situations. The force attached to an agent depends on what Bourdieu calls strengths which are differential factors of success and which may provide a competitive advantage (2005a, 75).

Furthermore, the Bourdieuian analysis operates with a variety of material and non-material forms of interchangeable capital. They represent forms of power within specific fields. These range from cultural capital in the form of educational credentials to financial capital. They also comprise social capital such as useful contacts and networks, to technological capital in the form of innovative technical equipment. One may further mention commercial forms such as brands, organizational capital that may take the form of a firm's reputation and symbolic (status) forms (see Bourdieu 1986).

Cultural, technical and commercial capital types exist in objectivized form such as equipment or instruments. They also exist in embodied form, literally linked to individual body possessing competences and skills. In other words, capital is inscribed in objective and subjective structures, which thereby turns into a "guarantor for the regularity and stability of the social world" (Svendsen and Svendsen 2004, 241). The embodied form of capital refers to "the external wealth converted into an integral part of the person, into a habitus" (Bourdieu 1986, 242). It cannot be transmitted 
instantaneously (unlike money or property rights) and remains marked by its earliest conditions of acquisition which determine its distinctive value. ${ }^{6}$

Social capital comprises the totality of resources, including financial capital and information, which may be activated through a more or less mobilizable network of relations that procures advantage by providing higher returns on investment (Bourdieu 2005b). One may consider that the volume of an agent's social capital is dependent on the size of the network of connections, which the individual can mobilize, and on the volume of capital (i.e., cultural, economic, or symbolic), possessed by the other members with whom the agent is connected (Bourdieu 1986, 249).

Most network approaches focus on the structure and content of ties. A prominent example is Uzzi (1997), who developed the notion of arm's length and emdedded ties. Furthermore, Granovetter (1988) discussed relational and structural ties. Finally, I would at least like to mention Coleman (1988) and Portes and Sensenbrenner (1993) whose work on the embeddedness as social capital marks a fundamental advancement in the field. In contrast, Bourdieu looked for the power attached to those ties. Such power is attributed to mutual recognition of capital based upon social network, group or class membership, or in other words social fields.

Each field facilitates a specific form of interest, a specific illusio, as tacit recognition, as the value of the "stakes of the game and as practical mastery of its rules" (Widick 2004, 201). One may argue that internal and external recognitions may be distinguished. Internal recognition (of capital) takes place within the field, for instance social capital in the form of strong ties that a person has built throughout his/her career. This social capital, to the extent that it is recognized as legitimate within the respective field, converts into a symbolic resource that functions in line with the rules of that field. ${ }^{7}$

External recognition, on the other hand, reflects the outside perspective. It refers for instance to the economic system and its assumptions about the value of each component of the field-specific capital for organizational production. These assumptions, in turn, signal to the economic field and thus influence its logic of capital transformation and conversion (Mayrhofer et al. 2004). The extent to which one can internally and externally recognize the capital is what helps in inferring the power relations of one field to another. This expanded concept of capital and its recognition can be viewed to complement the structural and relational analysis in the embeddedness tradition by integrating the symbolic dimension. It reminds one of Lévi-Strauss's idea that social reality is fundamentally symbolic. He argued that economic aspects derive from specific symbolic operations of definition, which constitute social order (see Bourdieu 1977).

Field characteristics can be analyzed and understood only by taking into account the entire interaction process of individuals (unequally) endowed in terms of economic, social and symbolic capital. Therefore, it is the heterogeneity of social positions that generates habitus and lifestyle (Bourdieu 1980). In contrast to the economists who consider individual preferences and beliefs as exogenous, Bourdieu aimed at analyzing the distribution and conversion of various forms of capital and 
their evolution over time. He contributed to an understanding of field formation through dynamic interactions of unequal agents, which can also be applied to various markets. He argued that the counter-position between unequal agents, in terms of the dominant and the dominated, introduces another dynamic aspect into the analysis. Each field hosts, therefore, struggles to maintain or transform the unequal distribution of capital.

Depending on the relative strengths that individuals can put into the struggle, the "space of possibles" constrains their choice of strategies to preserve or improve their capital (Bourdieu 1981a). The dominant may, for instance, cling to the strategies that would allow them to stabilize their position. Such stabilizing strategies would yield at the distribution of chances of success or barriers to entry. Similarly, the economic sociologist, Neil Fligstein $(1996,2001)$, whose work on markets is strongly informed by Bourdieu's field concept, argues that issues of internal organization revolve around producing stable social relations. He enhanced the field concept of his work on the market as a political field. According to his conception, markets are social constructions that are always co-constructed by the political-cultural rules and regulations of the state. Fligstein argued here very much on the lines of Bourdieu who said that the state shapes the market from inside and outside (Bourdieu 2005b; see also Mützel 2006).

Bourdieu's analysis is also concerned with destabilizing forces. Accordingly, the dominated, and new entrants would seek strategies to destabilize the current positions of strength. They would develop innovative strategies destined to devalue the capital that is held by the dominant. It would, as a consequence, allow for strategies of change, as opposed to more or less identical strategies of reproduction ad infinitum. Even though destabilization of a field is not the most frequent case, Bourdieu (2005a) asserts, particularly in his later works, the possibility of change that can be brought about by conflicting relations of unequal agents. Only a superficial or partial reading of his work may hence lead to an overestimation of the deterministic nature of structures as constraints to any dynamic transformation of the economic field.

\section{Habitus and Rational Choice}

The third criticism that is brought to the fore by Bourdieu concerns the principle of rationality. It is implicit in many embeddedness views, particularly in network analysis (for a detailed discussion, see Emirbayer and Goodwin 1994). While opposing economic orthodoxy, which conceives of individuals as homo economicus subjecting their decision making to rational calculation, and as actors performing their roles or acting mostly in conformity with models, Bourdieu (1977) proposes his concept of habitus.

With the habitus construct, he strongly rejected rational actors as actors without a past who are oriented to the future. He sets the habitus against the homo economicus that constantly keeps adapting its actions to some goals without reference to the social experience (Bourdieu 2005b, 211). However, his analysis has often been reduced to a 
Beckerian economist vision, too much inspired by neoclassical economics, because he put personal interests (material benefit and satisfaction) at the center of his model.

In what follows, the author will discuss selectively the principle of reasonability, as opposed to rationality adopted in neoclassical economics, the account of heterogeneity among agents and their interrelationship. A key point is Bourdieu's concern for social differences in the dispositions toward various kinds of behavior (rational or not). They open up to him avenues for an epistemological and methodological critique of the assumptions on the logic of action taken by rational choice models. Any empirically observed deviation should not just be regarded as irrationality or incomplete market as in a mechanical conception of the economy.

For Bourdieu, economic actors come to develop reasonable expectations, not rational expectations. They develop them by drawing on their habitus, which is referred to as a system of dispositions, thought, and perception. This habitus functions as a kind of cultural and social screen between the actor and reality (Bourdieu [1984] 1993, cf. Swedberg 2009). The interest of the habitus construct is to explicitly emphasize the reasons (which are to some extent endogenous) of the heterogeneity of agents.

While neoclassical theory assumes homogenous and equal actors, Bourdieu's agents apply different cognitive maps for their decisions in markets in which they are not equally related in terms of power, capacity, and information. The habitus, when shared among individuals, refers to "collective practice of the same modus operandi" that is central to collaborative work (Bourdieu 2005a, 76). Such collective practice is immediately foreseeable and intelligible, and taken for granted.

Market exchange is never given as economists might argue, but is socially and culturally constructed. Interaction is channeled by field properties and by forces that agents can put into their struggle. Bourdieu's study "Travail et travailleurs en Algérie" (Work and Workers in Algeria) brings evidence for this co-construction (Bourdieu 1963). It showed that the economic field had ultimately been transformed by modern capitalism. Most striking was the development of a new calculating and controlling spirit, which clashed with the culture of domestic economy in which the family provided the logic of exchange and people repeated what had always been done. In a similar vein, Franz Schultheis argued that capitalism facilitated the selection of a new ethos which made the homo economicus of his ideal-typical form to the entrepreneurial model well suitable to the emerging managerial profession (Schultheis 2006, 131).

Bourdieu $(1963,376)$ distinguishes between two types of economic agents: first, the rational entrepreneur who submits possibility to rational calculation; second, the economic adventurer who accepts the future to come and uses chances for his/her own purpose. The author agrees with Richard Swedberg (2009) who concludes that the Bourdieuian analysis allows a minimum of irrationality and with Rainer Diaz-Bone's (2006) argument on the existence of various rationalities. She acknowledged that the formal rationality, referred to as the capacity to methodologically and accurately carry out calculations, was only one out of many rationalities. 
Apart from rationalities, the habitus operates on the principle of adaptation. The adaptive habitus is part of the underlying grammar of action. It generates behaviors that are particularly well suited to the conditions from which they arise, which they tend to reproduce and with which they maintain social order (Bourdieu 2005a). ${ }^{8}$ Recruitment processes are a good example where actors attribute importance to the role of competence, skill, know-how and disposition, which resonate with certain types of capital and dispositions in a particular field, say a firm.

A study of French employers published in State Nobility: Elite Schools in the Field of Power empirically demonstrated the existence of considerable homology between the volume and structure (embodied and objectified) of the capital of firms and their directors (Bourdieu [1989] 1996). This internal structure was also closely related to the position of the firm in the overall economic context. This correspondence consisted of, on the one hand, the volume of the various firms' capital, and on the other, the structure of the capital distribution among various directors.

Similarly, career research by Hanappi (2007) and Mayrhofer et al. (2002) showed that career habitus, made up mainly of field-specific social and cultural capital, was a decisive factor in the advancement of one's position in the professional hierarchy. The main finding was that individuals with similar volumes and structures of capital were more capable to adapt to a certain firm and its internal structure of power positions. Indices for such structure of power positions within a firm might have taken the form of the hierarchical position of the labor force, the educational capital of the labor force, or the bureaucratic differentiation.

The most basic misunderstanding, however, concerning the concept of habitus is that it can be reduced to habit, that is according to Boyer (2008), the mechanical reproduction which leads to the disappearance of individual autonomy and, therefore, to a static history marked by permanent domination of the same holders of capital over the dominated (Caille 2002). Such conception is not without reason, because Bourdieu adopted a structuralist view in his earlier work, for instance, on educational systems (Bourdieu 1981b). However, in Rogers Brubaker's view (1996, 43), the notion of habitus includes subjects - active individuals and their dispositions, aspirations, expectations - in social explanation. This marks Bourdieu's distance from structuralist thought, and allows the author to include it as a supplementary factor for an analysis of change and innovation.

\section{Uncertainty, Change and Innovation in Bourdieu's Work}

Instead of calculating risks, as economists believe, Bourdieu's actors confront reality through a combination of structural constraint and spontaneity. The following quote reflects his understanding of habitus more explicitly:

Habitus is something that is powerfully generative. . . Habitus is a principle of invention, which, produced by history, is relatively independent of history: dispositions are lasting, something that leads to all 
sorts of effects of hysteresis (delay, discrepancy ... .). (Bourdieu 1980, 134 135)

What emerges from this definition is, first, that the strategies produce a response that is not pre-given in its direction in the stimulus, and that is not deducible from knowledge of the situation alone - the habitus is an active construct. Second, the conception of habitus is the trace of past trajectories that agents set in their strategies against the forces of the field. This makes up the historical dimension of habitus and is a main factor of field evolution.

Accordingly, Bourdieu (1980, 35) describes a strategy, in the form of an investment in a field, as the historical effect of agreement between two realizations of the social: in things (by institution) and in bodies (by incorporation). The matching of one with the other is only a special case when institutions and habitus are both products of the same historical process. The habitus, however, is neither necessarily adapted nor coherent and it can happen that dispositions fail to match the field and the collective expectations that control its working (Bourdieu 1997). A mismatch between the two would lead the field into crisis and cause disruption of regularities. Depending on one's perspective, such mismatch is, at the same time, a match with the group habitus intending to break with the dominating rules.

This theoretical perspective can be found throughout Bourdieu's work, no matter whether he talked about the single-family housing sector (Bourdieu 2005b), the redeployment strategies of the French elites (Bourdieu [1989] 1996), or the Algérian workers (Bourdieu 1963). The disruption of regularities may thus be viewed in two ways: First, as a consequence of a de-synchronization of field and habitus, or in other words, of a lack of correspondence between field and habitus (see also Florian 2006); second, the conception of the habitus is a cause for further field-habitus transformations. Such transformation may take the form of a reconfiguration of field structures, or the activation of new habitus facets.

Competition between the dominated and the dominating brings in a dynamic aspect. What is changed can cause a mismatch with the previous dominant habitus; so, to regain the former position and restabilize the former system, the formerly dominant individuals need to innovate. This breaks the chain of infinite reproduction. Despite the relatively stable core of cognitive schemes and dispositions, and considering over time, the habitus is a malleable construct. Such malleability bears the potential for structural change, which in turn may transform the habitus itself. The habitus is transformed if the more or less binding rules of practical reason are recognized as reasonable by the agents' practices and rules of thumb, pre-reflexive, unconscious style and ethos. In other words, the binding rules and their objective constraints get institutionalized when incorporated into reasonable orientations for action in the habitus dispositions. Similarly, Crossley (2001) states that patterns and underlying principles of social contexts are incorporated in the habitus as both an inclination and a modus operandi. ${ }^{9}$

If one now considers the social and cognitive factors, he or she may find a starting point to look at pre-conditions to activate, reproduce, and transform the 
space of institutional constraints and opportunities. Actors incorporate social structures and by doing so produce external effects. These are relatively independent of the actors, so that some "space of possibles" as Bourdieu calls it, is activated or newly created. Actors are granted certain autonomy to behave spontaneously and creatively, and to depart from collective practice. This suggests that Bourdieu's actors face uncertainty, which the habitus is supposed to practically master (Bourdieu 2005b).

What notion of uncertainty does Bourdieu's work implicitly assume for the underlying logic of economic behavior? And, do most classical assumptions about uncertainty in economic literature apply to social reality as seen in Bourdieu's theory? An attempt is made in the following paragraphs to answer these questions, particularly with reference to the two notions of uncertainty, which are considered most important to the theoretical deliberations made above: procedural uncertainty and fundamental uncertainty.

In The Social Structures of the Economy (2005b, 15), Bourdieu argues that the habitus helps to practically master uncertainty. This uncertainty is said to result from people's limited computational and cognitive capabilities in complex situations. Such understanding of uncertainty is generally referred to in economics literature as procedural uncertainty, which is closely linked to the notion of bounded rationality as proposed by Herbert Simon (1957). In this case, economic reality is complex and populated by individuals with limited capabilities, given the available information.

To look at the rationality of action, a prominent sociological approach has been made by Jens Beckert. Beckert $(1996,2003)$ builds his critique against economic theorizing, not on the action-model of homo economicus per se but on the underlying assumption that economic actors can, even in complex situations, deduce their actions from a preference ranking and thereby maximize their utility. He introduces the term intentional rationality, which shifts the focus away from the dichotomy of rational versus irrational behavior implicit in Simon's theory. The notion of intentional rationality, instead, concentrates on the means-ends relationship, that is, the wish to achieve a goal that optimizes one's utility without knowing the best means to apply for realizing that goal. If one looks at procedural uncertainty, Beckert's intentionally rational actors choose innovative strategies whose efficiency cannot be anticipated.

In Bourdieu's sociological approach, however, such a rationale may apply only to a limited number of situations, and implies only one type of rationality (most closely to the calculating spirit of modern capitalism). It omits situations characterized by the lack of all the information that would be necessary to make decisions with certain outcomes as described by Dosi and Egidi (1988). Dequech (1997) differentiates such conditions into weak and strong forms of uncertainty. Whereas the weak version is tied to Savage's standard expected utility (SEU) theory, the latter is characterized by the absence of unique, additive and fully reliable probability distributions (see also Clark 1997; Denzau and North 1994). ${ }^{10}$

This strong form of uncertainty is at least implicitly assumed in Bourdieu's conceptualization of the "space of possibles" that implies the existence and emergence 
of relatively independent field forces which spontaneous and creative agents encounter and practically master. As a consequence, even the most sophisticated economic agent cannot state a list of certain outcomes ranked in terms of their values. For this sociological treatment of uncertainty, one may refer to fundamental uncertainty as defined by Dequech (2006) in economics literature. Dequech recognized, as North (1999) points out, that this form of uncertainty is based on the notion of non-ergodicity, which describes the world as ever changing in novel ways. It is characterized by the possibility of creativity and non-predetermined structural change.

On the lines of Schumpeter's (1989) argument - and if reformulated, in sociological terms - agents must innovate and be active to be able to compete in the market field. On the contrary, if the habitus were a passive construct only and the results could not be known owing to people's limited capabilities to deal with complex reality, then such theory would speak for rule-following and reproductive behavior. This behavior would be more appropriate in such situations than under fundamental uncertainty. In addition, the author shares and reformulates Dequech's argument (2001, 922): Fundamental uncertainty is compatible with social reality; the latter is subject to non-predetermined structural change, but may also be complex and people's habitus may also constrain their cognitive capabilities. In other words, personal history shapes the way one perceives things.

Finally, one may argue for situations of procedural uncertainty wherein individuals are assumed to adopt a satisficing rather than an optimizing strategy. They search for satisfactory solutions, given some aspirational levels, as Simon argued. Rationality is treated as an individual matter, aspirations being exogenous. Bourdieu's theory would instead account for different levels and qualities of aspirations and dispositions. Decision makers would adopt reasonable strategies that suit their social environment, and their expectations of what is practically possible and suitable to their situation. Economic reasoning is treated neither as a strictly individual nor as a collective mechanism; to him, it is an encounter with both. This notion would stress that agents with individual aspirations incorporate collective aspiration levels into their action. These in turn create external, agent independent effects on the field as such.

One form of strategic action is signaling to convey information to others (Feldman and March 1981). Such signaling is particularly relevant to highly competitive markets where parties must deal with conflicts, handle all kinds of uncertainty, provide novel products, and develop innovative strategies. It is central to White's market model, which is one of the most prominent network approaches that advances the account for the structural and cultural elements of economic action in social analysis. That is why it is shown subsequently in the way Bourdieu's understanding of the economy is different from that of White. 


\section{The Case of Signaling}

Now, this last set of considerations allows one to shift the focus away from the analytical conceptualization of social structures and action, as held in Bourdieu's theory, and the role of uncertainty - the main topic of the preceding section - onto the concrete accounts of social structure and uncertainty in White's work.

In Identity and Control, White (1992) builds on Spence's signaling model (1976, 2002) that treats markets as they are, rather than as markets embedded in social structures (networks). Two aspects make this point most evident: the conceptualization of quality, and its assessment. First, in the original model by Spence, quality is considered an inherent attribute, a separate individual ability. This ability spreads along the whole continuum of talent of a big pool of individuals; the continuous distribution over talent is considered an index of quality. ${ }^{11}$ Second, the assessment of quality is considered primarily cognitive and neglectful of the representation of social structure.

In contrast, many network analysts employ a different approach and attempt to conceptualize social structure (for a relational approach, see McAdam 1986 and Rosenthal et al. 1985; for a positional analysis, see Bearman 1993 and Lorain and White 1971). On the positional side, the early White and related scholars present network data that describes change over time (White, Boorman and Breiger 1976, 763-768); they assume that markets are socially constructed, because they are based on social role and network configurations by actors of equivalent relations (see Lorain and White 1971).

White's concept of networks resembles analytically that of Bourdieu's fields (Bourdieu and Wacquant 1992, 114). What distinguishes White's work, particularly his early work, from that of Bourdieu is his account of the processes of structural transformations. His delineation of structural processes does not include individual manipulations that shape cognitive schemes, such as those related to the notion of habitus. Second, White's approach adheres to the model of homo economicus, which is implicit in the assumption that network agents who behave instrumentally are utility maximizers, which in fact comes from the domain of rational choice theory.

In his more recent works, White took a significant theoretical step in an alternative direction. In Identity and Control (1992), he suggests an interrelationship between motivations and identities, and social structures. He accounts for the subjective and argues that one sense of identity is that of a social face, the basis

for our everyday constructs for the person ... as an actor in a role [supplying] preferences that may guide him or her towards goals, and into rational action (314-315).

This new approach also shapes his network-based market model that builds on a modified rational choice model of individual action. In his later work, Markets from Networks (White 2002, 296) he reformulates rationality as a "collection of habits derived from and ensconced only through interaction and subsequently reinforced." 12 
However, the crucial issue is not so much of rationality as of the method of construing and signaling with respect to meanings and measures of quality. Being a leading exponent of structuralist determinism in his earlier days, White turned, in his market modeling, to matching the processes of buyers and sellers who mutually signal their interests and qualifications. His idea was that signals, in terms of activities, illustrated one's identity through prior personal history. For example, one's educational credentials are included in the basic model, specific competences and skills, and relationships (see Jones 2002).

Signals also include relatively fixed attributes, described as indices (Goffman 1959; Spence 1973) such as age, ethnicity, gender, and nationality. Exchange parties try to infer how these indices will influence a match. Signals, as activities and attributes, transmit information to others; they take place under conflicts of interest and are conveyed with an anticipation of decisions (Feldman and March 1981). White (2002) formulates that signalers do not perceive demand curves; instead they perceive choices of others, or what is called a generalized market schedule of observed outcomes on the basis of which they make their decisions. Based on such a schedule, observers can infer the performance of the signaler based on the meaning of the signal and the context in which it is sent.

How does White account for the uncertainty in his network-based model? According to White, uncertainty facilitates the construction of some sort of institution, a market. The market depends on the common actors' perception of a schedule of wages that could be expected in response to various signals of quality. The implicit assumption is one of bounded rationality implying procedural uncertainty or, in more substantive cases, ambiguity (see Dequech 2001, 916). The latter case refers to situations in which "information may become available to the decision makers, changing their probability distributions and/or their assessment of the reliability of these distributions."

Ambiguous signals are then interpreted in light of a person's past experiences. Those who have more experience in attending signals and seeing the outcome of decisions (e.g., hiring) will be able to reduce such ambiguity. If one can thus reduce ambiguity, people may wish to wait for more information and thus temporarily refuse to bet under ambiguity by revealing any subjective probabilities. They would wait until they have collected what Jones $(2002,211)$ called signaling expertise.

However, what would motivate actors if some types of information will never be obtained ex ante, no matter how long they wait? Despite its high importance for network theory, White's approach does not really explain the motivation of individual action on the basis of the historical transformation of past trajectories and the evolution of dispositions and preferences guiding action as proposed in Bourdieu's field and habitus approach. This drawback, it is argued, would be even more evident under fundamental uncertainty. Normative commitments and values would play an ever more important role to shape orientations and aspirations of historical actors. 


\section{Conclusion}

Despite numerous scholarly contributions in economic sociology over the past decades, social theorists and network scholars could not so far reach their full potential to systematically examine the fundamental theoretical presuppositions of individual action. The differences in terminology and methodology between the two research strands have probably prevented them from any further substantial crossfertilization and dialogue.

This article has shown how Bourdieu's approach actually responds to the key criticism of the embeddedness tradition, namely that induced economic sociology to prioritize the analysis of structural forces over the question of the subjective and historical foundations of individual action. Its principal achievement, it is argued, has been to transform a merely a-historical understanding of individual actors located in social fields into a more precise, theoretical concept for social analysis. It has also been suggested, that despite its powerful conceptualizations of the interrelationship between social structure and agency, this approach, having been developed up to date, has only implicitly theorized the conditions under which actors tend to innovate, rather than reproduce; as a result, the potential of the generative habitus for the moment of creating novel strategies has often been overseen in the very conceptualization of social action.

Bringing this argument to the fore allows one to provide, particularly the network analysts, with a strong conceptualization of the actor as a historical and heterogeneous entity, probably at the cost of losing focus on meso-dynamics in networks. The position taken here is that of complementing network approaches with an agent-based construct of economic reason as proposed by Bourdieu. This would allow for a dynamic view of socially constructed action undertaken by agents using the power attached to them by virtue of their position. It also depends to a considerable extent on the pre-understanding or apprehension of certain stimuli, which the author currently illustrates by signals and strategies attached to them. The suggestion advanced here is that economic sociology should enhance its analysis of economic action by linking micro- and macro-levels systematically to advance its understanding of historical and cognitive factors for a more comprehensive conception of economic action.

\section{Notes}

1. Granovetter generalized a concept of social action as embedded in social networks. He noted that "actors do not decide as atoms outside the social context, nor do they adhere slavishly to a script written for them by the particular intersection of social categories that they happen to occupy" $(1985,487)$. In this way, he conceptualized action as embedded in social networks that is not generated by the particular intersection of social categories.

2. Bourdieu's approach to economic issues of new economic sociology can be located in his studies on "Work and Workers in Algeria" (1963), as well as his later work on The Social Structures of the Economy (2005b). His contribution on "The Principles of an Economic Anthropology" (2005a) focuses on core economic phenomena, such as market preferences, strategies, or decision making (for a detailed discussion see Diaz-Bone 2006 and Florian 2006). 
3. With his understanding of the economy, Bourdieu put himself in opposition to the interactionist's vision (Cooley [1902] 1964; Mead 1934). The latter places at its center the influence directly exerted by one firm over another through any kind of interaction.

4. In a similar vein, Callon (1998) calls the embedding of market in economic sciences a theory effect.

5. This account reminds one of the circularity referred to by Durkheim (1922) in his works on the relation between society and the individual, even though Bourdieu places greater relevance on individual dispositions and the competence of improvisation. This stands in contrast to Durkheim's stronger mechanistic vision (Crossley 2001).

6. Its transmission is best hidden, so that it receives higher weight in the reproduction of the field than direct, tangible forms that are more strongly controlled. Bourdieu's view may thus be conceived as being rooted in anticipation of the distinction between the two states of capital - the objectified and the embodied - which have been spelled out in "The Instinct of Workmanship" by Thorsten Veblen (1898).

7. As a power in terms of brand loyalty, or as a commitment to a firm in the case of employees, symbolic capital functions as a form of credit. It presupposes the people's trust and belief upon which it bears, because they are supposed to grant it credence.

8. In contrast, pragmatists' views suggest that any habit or rule of action already implies the perception of situations that already incorporate a judgment on the appropriateness of certain kinds of action (Bandelj 2009; Joas 1996, 160).

9. One may refer to Fazio's (1990) work here. Contrary to Etzioni's approach, which remains in the rational calculus (even though normative), Fazio's routinized behavior is a short cut based on individual history. It is similar to the way in which habitus represents a short cut of personal history.

10. Here, the author follows Dequech's interpretation of strong uncertainty, rather than Furubotn and Richter (2005) who seem to interpret Denzau and North (1994) in terms of procedural uncertainty.

11. No systematic distinction between the level of the signal and its associated quality was made, which would be relevant to the evaluation of the signaler's productivity (see White 2002). For modified versions of Spence's basic model, see, for instance, George Akerlof (1970) and Winter and Phelps (1970).

12. In a similar way, Friedman and McAdam (1992) claim that network theory needs a model of rationality which allows for collective identities (and not just material resources) as a potentially powerful motivator for action.

\section{References}

Akerlof, George A. “The Market for 'Lemons': Quality Uncertainty and the Market Mechanism.” Quarterly Journal of Economics 84, 3 (1970): 488-500.

Arestis, Philip. The Post-Keynesian Approach to Economics. Aldershot: Edward Elgar, 1992.

Bandelj, Nina. "Emotions in Economic Action and Interaction." Theory and Society 38, 4 (2009): 347-366.

Bearman, Peter. Relations into Rhetorics: Local Elite Social Structure in Norfolk, England, 1540-1640. New Brunswick, NJ: Rutgers University Press, 1993.

Beckert, Jens. "What is Sociological about Economic Sociology? Uncertainty and the Embeddedness of Economic Action." Theory and Society 25, 6 (1996): 803-840.

__. "Economic Sociology and Embeddedness: How Shall We Conceptualize Economic Action?" Journal of Economic Issues 37, 3 (2003): 769-788.

Bourdieu, Pierre. "Travail et travailleurs en Algérie: Etude sociologique." In Travail et travailleurs en Algérie, pp. 257-562. Paris: Mouton \& Co., 1963.

- Outline of a Theory of Practice. Cambridge: Cambridge University Press, 1977.

—. Le Sense Pratique. Paris: Minuit, 1980.

_. "The Educational System and the Economy: Titles and Jobs." In French Sociology: Rupture and Renewal Since 1968, edited by Charles Lemert, pp. 141-152. New York: Columbia University Press, 1981a.

_- "Structures, Strategies, and the Habitus." In French Sociology: Rupture and Renewal Since 1968, edited by Charles Lemert, pp. 86-97. New York: Columbia University Press, 1981b.

—. Distinction: A Social Critique of the Judgement of Taste. London: Routledge, 1986. 
—. Sociology in Question. London: Sage; Paris, Les Editions de minuit, [1984] 1993.

—. The State Nobility: Elite Schools in the Field of Power, translated by L.C. Clough. Cambridge: Polity, [1989] 1996.

—. "Principles of an Economic Anthropology." In The Handbook of Economic Sociology, edited by Neil Smelser and Richard Swedberg, pp. 75-89. Princeton: Princeton University Press, 2005a.

- The Social Structures of the Economy. Cambridge: Polity, 2005b.

Bourdieu, Pierre, and Loï Wacquant. An Invitation to Reflexive Sociology. Chicago: University of Chicago Press, 1992.

Boyer, Robert. "Pierre Bourdieu, a Theoretician of Change: The View from Regulation Theory." In The Institutions of the Market: Organisations, Social Systems, and Governance, edited by Nikolaus Beck and Alexander Ebner, pp. 348-397. New York: Oxford University Press, 2008.

Brubakers, Rogers. "Rethinking Classical Theory: The Sociological Vision of Pierre Bourdieu." In After Bourdieu: Influence, Critique, Elaboration, edited by David L. Swartz and Vera L. Zolberg, pp. 25-64. Dordrecht: Kluwer, 1996.

Caillé, Alain. Don, Intérêt et Désinteressement. Paris: La Découverte, 2002.

Callon, Michel. "Actor-Network Theory, The Market Test." In Actor Network Theory and After, edited by Hassard Jlaj, pp. 181-195. Oxford: Blackwell, 1998.

Clark, Andy. "Economic Reason: The Interplay of Individual Learning and External Structure." In Frontiers of Institutional Economics, edited by John Drobak and John Nye, pp. 269-290. San Diego: Academic Press, 1997.

Cooley, Charles H. Human Nature and the Social Order. New York: Schocken Books, [1902] 1964.

Coleman, James S. "Social Capital in the Creation of Human Capital." American Journal of Sociology 94 (1988): 95-120.

Crossley, Nick. "The Phenomenological Habitus and its Construction." Theory and Society 30, 1 (2001): 81 120.

Denzau, Arthur and Douglass North. "Shared Mental Models: Ideologies and Institutions." Kylos 47(1994): 3-31.

Dequech, David. "Uncertainty in a Strong Sense: Meaning and Sources." Economic Issues 2 (1997): 21-44.

_ . "Bounded Rationality, Institutions, and Uncertainty." Journal of Economic Issues 35, 4 (2001): 911-929. "The New Institutional Economics and the Theory of Behaviour under Uncertainty." Journal of Economic Behavior $\mathbb{E}$ Organization 59 (2006): 109-131.

Diaz-Bone, Rainer. "Wirtschaftssoziologische Perspektiven nach Bourdieu in Frankreich.” In Pierre Bourdieu: Neue Perspektiven für die Soziologie der Wirtschaft, edited by Michael Florian and Frank Hillebrandt, pp. 43-72. Wiesbaden: VS Verlag, 2006.

Dosi, Giovanni and Massimo Egidi. "A Bounded Rationality Approach to Uncertainty and Innovation." In Between Rationality and Cognition, edited by Miriam Campanella, pp. 99-111. Turin-Geneva: Albert Meynier, 1988.

Durkheim, Emile. Education et sociolgie. Paris: Falconnet, PUF, 1922.

Emirbayer, Mustafa and Jeff Goodwin. "Network Analysis, Culture, and the Problem of Agency." American Journal of Sociology 99, 6 (1994): 411-454.

Fazio, Russell. "Multiple Processes by which Attitudes Guide Behavior: The Mode Model as an Integrative Framework." Advances in Experimental Social Psychology 23 (1990): 75-109.

Feldman, Martha and James March. "Information in Organizations as Signal and Symbol." Administrative Science Quarterly 26, 2 (1981): 171-186.

Fligstein, Neil. "Markets as Politics: A Political-Cultural Approach to Market Institutions." American Sociological Review 61, 4 (1996): 656-673.

—. The Architecture of Markets. Princeton: Princeton University Press, 2001.

Florian, Michael and Frank Hillebrandt. Pierre Bourdieu: Neue Perspektiven für die Soziologie der Wirtschaft. Wiesbaden: VS Verlag, 2006.

Florian, Michael. “Ökonomie als soziale Praxis.” In Pierre Bourdieu: Neue Perspektiven für die Soziologie der Wirtschaft, edited by Florian Michael and Frank Hillebrandt, pp. 73-108. Wiesbaden: VS Verlag, 2006. 
Friedman, Debra and Dow McAdam. "Collective Identity and Activism: Networks, Choices, and the Life of Social Movement." In Frontiers in Social Movement Theory, edited by Aldon D. Morris and Carol McClurg Mueller, pp. 156-173. New Haven and London: Yale University Press, 1992.

Fuhse, Jan and Sophie Mützel. Relationale Soziologie: Zur kulturellen Wende der Netzwerkforschung. Wiesbaden: VS Verlag, 2010.

Furubotn, Eirik and Rudolf Richter. Institutions and Economic Theory: The Contribution of the New Institutional Economics. Ann Arbor: University of University Press, 2005.

Garcia, Marie-France. "La Construction Sociale D'un Marche Parfait: Le Marche Au Cadran De FontainesEn-Sologne." Actes de la Recherche en Sciences Sociales 65 (1986): 2-13.

Garner, Alan. "Uncertainty, Human Judgment, and Economic Decisions." Journal of Post Keynesian Economics 4, 3 (1982): 413-424.

Goffman, Ervin. The Presentation of Self in Everyday Life. New York: Doubleday, 1959.

Granovetter, Marc. "Economic Action and Social Structure: The Problem of Embeddedness." American Journal of Sociology 91, 3 (1985): 481-510.

_- "The Sociological and Economic Approaches to Labor Market Analysis: a Social Structural View: Economic and Sociological Approaches." In Industries, Firms, and Jobs, edited by George Farkas and Paula England, pp. 187-216. New York: Plenum, 1988.

Hanappi, Doris C. Early Careers of Managers and Young Professionals an Integrative Approach to Contemporary Careers. Mering: Hampp, 2007.

Joas, Hans. The Creativity of Action. Chicago: University of Chicago Press, 1996.

Jones, Candace. "Signaling Expertise: How Signals Shape Careers in Creative Industries." In Career Creativity: Explorations in the Remaking of Work, edited by Maury Peiperl, Michael Arthur and Bharat Anand, pp. 209-228. Oxford: Oxford University Press, 2002.

Knight, Frank. Risk, Uncertainty and Profit. Boston and New York: Kelley, 1921.

Lorrain, Francoise and Harrison White. "Structural Equivalence of Individuals in Social Networks." Journal of Mathematical Sociology 1, 1 (1971): 49-80.

Mayrhofer, Wolfgang, Michael Meyer, Alexandre Iellatchitch and Michael Schiffinger. "Careers and Human Resource Management - A European Perspective.” Human Resource Management Review 14, 4 (2004): 473-498.

Mayrhofer, Wolfgang, Michael Meyer, Johannes Steyrer, Alexandre Iellatchitch, Michael Schiffinger, Guido Strunk, Christiane Erten-Buch, Anett Hermann, and Christine Mattl. "Einmal Gut, Immer Gut? Einflussfaktoren auf Karrieren in, neuen 'Karrierefeldern." Zeitschrift für Personalforschung 16, 3 (2002): 392-414.

McAdam, Doug. "Recruitment to High-Risk Activism: The Case of Freedom Summer." American Journal of Sociology 92, 1 (1986): 64-90.

Mead, George. Mind, Self and Society. Chicago: University of Chicago Press, 1934.

Mützel, Sophie. "Strukturelle Neztwerkanalyse und Bourdieus Praxistheorie." In Pierre Bourdieu: Neue Perspektiven für die Soziologie der Wirtschaft, edited by Michel Florian and Frank Hillebrandt, pp. 109. 126. Wiesbaden: VS Verlag, 2006

Nelson, Richard and Sidney Winter. An Evolutionary Theory of Economic Change. Cambridge: Harvard University Press, 1982.

—_. "Evolutionary Theorizing in Economics." Journal of Economic Perspectives 16, 2 (2002): 23-46.

North, Douglas. "Orders of the Day." Reason 31, 6 (1999): 58-59.

Polanyi, Karl. The Great Transformation: The Political and Economic Origins of Our Time. Boston: Beacon, [1944] 2001.

Portes, Alejandro and Julia Sensenbrenner. "Embeddedness and Immigration: Notes on the Social Determinants of Economic Action." American Journal of Sociology 98, 6 (1993): 13-20.

Powell, Walter and Paul DiMaggio. The New Institutionalism in Organizational Analysis. Chicago: University of Chicago Press, 1991.

Rosenthal, Naomi, Meryl Fingrudt, Michele Ethier, Roberta Karant and David McDonald. "Social Movements and Network Analysis: A Case Study of Nineteenth-Century Women's Reform in New York State." American Journal of Sociology 90 (1985): 1022-1054.

Schumpeter, Joseph A. Essays: On Entrepreneurs, Innovations, Business Cycles, and the Evolution of Capitalism. New Brunswick: Transaction Publishers, 1989. 
Schultheis, Franz. "Die Metamorphosen der sozialen Frage in Zeiten des neuen Geistes des Kapitalismus.” In Soziale Milieus und Wandel der Sozialstruktur, edited by Helmut Bremer and Andrea Lange-Vester, pp. 128-140. Wiesbaden: VS Verlag, 2006.

Simon, Herbert A. Administrative Behavior. New York: Macmillan, 1957.

Spence, Michael. "Job Market Signaling.” Quarterly Journal of Economics 87, 3 (1973): 355-374.

—. Market Signaling: Informational Transfer in Hiring and Related Screening Processes. Cambridge: Harvard University Press, 1974.

—. "Competition in Salaries, Credentials, and Signaling Prerequisites for Jobs.” Quarterly Journal of Economics 90, 1 (1976): 51-74.

_. "Signaling in Retrospect and the Informational Structure of Markets." American Economic Review 92, 3 (2002): 434-459.

Swedberg, Richard. "The Economic Sociologies of Pierre Bourdieu.” CSES Working Paper Series, no. 51. New York: Center for the Study of Economy and Society, 2009.

Svendsen, Gunnar Lind Haase and Gert Tinggaard Svendsen. "On the Wealth of Nations: Boudieuconomics and Social Capital.” In After Bourdieu: Influence, Critique, Elaboration, edited by David L. Swartz and Vera L. Zolberg, pp. 239-267. Dordrecht: Kluwer, 2004.

Uzzi, Brian. "Social Structure and Competition in Interfirm Networks: The Paradox of Embeddedness." Administrative Science Quarterly 42, 1 (1997): 35-67.

Veblen, Thorstein. "The Instinct of Workmanship and the Irksomeness of Labor." American Journal of Sociology 4, 2 (1898): 187-201.

White, Harrison, Scott Boorman and Ronald Breiger. "Social Structure from Multiple Networks. I. Blockmodels of Roles and Positions." American Journal of Sociology 81, 4 (1976): 730-780.

White, Harrison. "Where Do Markets Come From?" American Journal of Sociology 87, 3 (1981): 517-547.

-. Identity and Control: A Structural Theory of Social Action. Princeton: Princeton University Press, 1992.

- Markets from Networks: Socioeconomic Models of Production. Princeton: Princeton University Press, 2002.

Widick, Richard. "Flesh and the Free Market: On Taking Bourdieu to the Options Exchange." In After Bourdieu: Influence, Critique, Elaboration, edited by David L. Swartz and Vera L. Zolberg, pp. 193-238. Dordrecht: Kluwer, 2004.

Winter, Sidney and Edmund Phelps. "Optimal Price Policy under Atomistic Competition." In Microeconomic Foundations of Employment and Inflation Theory edited by Edmund S. Phelps, pp. 309. 337. London: Macmillan, 1970. 
